\title{
PELAKSANAAN PENDAFTARAN PERALIHAN HAK ATAS TANAH BEKAS ADAT YANG BELUM BERSERTIFIKAT (STUDI DI DESA AMBIT KECAMATAN WALED KABUPATEN CIREBON)
}

\author{
Melatul Aliyah $^{1 *}$, Fifik Wiryani ${ }^{2}$, Isdian Anggraeny ${ }^{3}$ \\ ${ }^{123 *}$ Fakultas Hukum, Universitas Muhammadiyah Malang, Malang \\ *Koresponden: melatulaliyah23@gmail.com
}

\begin{abstract}
This study aims to find out all procedures for the transfer of rights to ex-customary land that have not been certified along with the requirements that must be completed to register the transfer of rights to ex-customary land that has not been certified as well as to find out the problems faced by the people of Ambit Village related to the registration of the transfer of rights to land. former customs and solutions for their solutions. The research method used is field research with an empirical juridical approach that is based on field research and interviews and is adapted to legal conditions. The results of the study can be concluded that the registration of the transfer of rights to former customary land that has not been certified in Ambit Village has been carried out in accordance with the provisions of the government regulation of land registration No. 24 of 1997. There are several problems that arise in the process of registering the transfer of rights to former customary land that has not been certified, such as land parcels that are still in dispute and there is no proof of SPPT PBB payment from the previous owner. It can be concluded that the community must follow the procedure and register their land with complete required documents and pay taxes on time.
\end{abstract}

Keywords: Land; Custom; Certificate; Transition

\begin{abstract}
Abstrak
Penelitian ini bertujuan untuk mengetahui seluruh prosedur peralihan hak atas tanah bekas adat yang belum bersertifikat beserta persyaratan-persyaratan yang harus dilengkapi untuk mendaftarkan peralihan hak atas tanah bekas adat yang belum bersertifikat serta mengetahui permasalahan yang dihadapi oleh masyarakat Desa Ambit terkait dengan pendaftaran peralihan hak atas tanah bekas adat beserta solusi penyelesaiannya. Metode penelitian yang digunakan adalah penelitian lapangan dengan pendekatan yuridis empiris yang didasarkan pada penelitian lapangan dan wawancara serta disesuaikan dengan keadaan hukum. Hasil penelitian dapat disimpulkan bahwa Pelaksanaan pendaftaran peralihan hak atas tanah bekas adat yang belum bersertifikat di Desa Ambit telah dilaksanakan sesuai dengan ketentuan peraturan pemerintah pendaftaran tanah No. 24 Tahun 1997. Terdapat beberapa permasalahan yang timbul dalam proses pendaftaran peralihan hak atas tanah bekas adat yang belum bersertifikat seperti bidang tanah masih dalam keadaan sengketa serta tidak ada bukti pembayaran SPPT PBB dari pemilik sebelumnya. Dapat disimpulkan bahwa masyarakat harus mengikuti prosedur dan
\end{abstract}


mandaftarkan tanahnya dengan dokumen persyaratan lengkap serta membayar pajak tepat waktu.

Kata Kunci: Tanah; Adat; Sertifikat; Peralihan

\section{A. PENDAHULUAN}

Keberadaan tanah semakin hari semakin meningkat seiring dengan perkembangan zaman dan cepatnya pembangunan di segala bidang serta kondisi Indonesia yang agraris dengan beragam jenis tanah. Pasal 33 ayat 3 UUD 1945 menjelaskan bahwa bumi, air dan kekayaan alam yang terkandung didalamnya dikuasai oleh Negara dan dimanfaatkan sebesar-besarnya untuk kesejahteraan rakyat. Negara memiliki peran terhadap tanah yang sifatnya menguasai, bukan memiliki yang berarti Negara mempunyai hak milik atas tanah atau memiliki tanah. Penguasaan tanah Negara bersifat hukum publik dan perdata sesuai dengan pasal 2 ayat 2 UUPA yang menyatakan untuk memastikan dan mengatur yang berkaitan dengan keterkaitan hukum antara orang dengan bumi, air dan angkasa.

Pelaksanaan hukum publik dan hukum perdata bertumpu pada pasal 2 ayat 2 UUPA. Ketentuan ayat 1 mengatur kewajiban Negara menurut hukum publik akan tetapi dalam ketentuan angka 2 dan 3 kewenangan negara berdasarkan hukum perdata. Peralihan hak atas tanah, pertama harus memperhatikan ketetapan khususnya peralihan hak atas tanah yang merupakan bagian dari pendaftaran tanah. Ketetapan dalam mengatur pendaftaran tanah salah satunya peralihan hak atas tanah telah dimuat pada pasal 19 UUPA dan peraturan pelaksanaanya. Dalam perkembangannya ketetntuan ini kemudian diganti dengan Peraturan Pemerintah No. 24 Tahun 1997 tentang Pendaftaran Tanah. Yang mana dalam PP ini diadakan simplifikasi dan prosedur dalam penyelenggaraan pendaftaran tanah.

Peralihan hak atas tanah merupakan pemindahan hak dari satu pihak ke pihak lain. Hak milik atas tanah yaitu hak milik yang merupakan hak yang kuat, turun menurun dan mampu dimiliki oleh setiap orang dimana tujuan dan penggunannya harus berfungsi sosial. Pendaftaran peralihan hak atas tanah adalah pencatatan peralihan hak atas tanah, pencatatan administrasi atau cara beralihnnya kepunyaann suatu bidang tanah dari pihak satu ke pihak lainnya. Agar terdapat kepastian hukum dari hak-hak atas tanah maka harus mendaftarkan tanahnya dikantor pertanahan setempat. Pemilik hak atas tanah jika diadakan peralihan hak atas tanah yang mana ini memiliki tujuan untuk pemindahan hak dari pihak satu ke pihak lain wajib dibuktikan dengan akta yang dibuat dihadapan Pejabat Pembuat Akta Tanah yang selanjutnya disebut PPAT yang ditunjuk oleh kepala BPN. Sebagaimana telah ditetapkan daIam Peraturan Pemerintah Pendaftaran Tanah No. 24 Tahun 1997 pada pasal 37 ayat (1) dan (2) dan pasal 38 ayat (1) dan (2).

Berdasarkan Peraturan Pemerintah tentang Peraturan Jabatan Pejabat Pembuat Akta Tanah No. 37 Tahun 1998 menyatakan bahwa ada 3 macam PPAT yaitu: Pejabat Pembuat Akta Tanah (PPAT), PPAT sementara (Camat atau Kepala Desa), PPAT Khusus (Pejabat Badan Pertahanan Nasional (BPN)). Dari tiap-tiap PPAT mempunyai wewenang untuk pembuatan Akta autentik sesuai dengan kewenangan yang diberikan oleh undang-undang. Jika dalam daerah tidak ada PPAT ataupun sudah tetapi jumlahnya tidak cukup untuk melayani keperluan masyarakat dalam pembuatan akta-akta yang berkaitan dengn tanah terutama akta tanah yang 
belum bersertifikat maka untuk sementara pemerintah menugaskan camat sebagai Pejabat Akta Tanah Sementara dalam hal melayani kepentingan masyarakatnya.

Pengertian Pendaftaran tanah didalam PP No. 24 Tahun 1997 adalah penyelesaian dari ruang lingkup pelaksanaan kegiatan pendaftaran tanah yang berdasarkan pada pasal 19 ayat (2) Peraturan Pemerintah Nomor 10 Tahun 1961 yang meliputi: pengukuran, pemetaan, dan pembukuan tanah serta pendaftaran dan peralihan hak atas tanah yang diikuti dengan pemberian mengenai tanda bukti hak sebagai alat pembuktian yang terkuat. ${ }^{12}$

Kegiatan pendaftaran tanah pertama kali ini ada 2 cara yakni Sistcmatik dan Sporadik. Kegiatan pendaftaran tanah sistcmatik yaitu kegiatan pendaftaran tanah pertama kali dan dalam pelaksanaannya secara bersama atau serentak yakni termasuk semua obyek pendaftaran tanah yang belum pernah terdaftar didalam daerah atau dibagian suatu wilayah desa atau kelurahan. Sedangkan sporadic yaitu kegiatan pendaftaran tanah pertama kali yang dilakukan hanya satu bahkan beberapa objek pendaftaran tanah dlam suatu wilayah desa atau kelurahan secara individu.

Kabupaten Cirebon adalah bagian dari wilayah Provinsi Jawa Barat yang tepatnya terdapat dibagian timur yang mana bertepatan dengan batas wilayah Jawa Tengah dengan Jawa Barat. Di wilayah Kabupaten Cirebon Jawa Barat khususnya desa ambit pembuatan akta-akta yang berkenaan dengan tanah maka Camat yang ditunjuk selaku PPAT sementara. Maka dari itu jika terjadinya jual beli tanah bekas adat yang belum terdaftar ataupun karna suatu hal lain yang mengakibatkan beralihnya kepemilikan tanah tersebut maka harus dilakukan pendaftaran ulang yang mana pendaftaran ini nantinya memerlukan identitas dari pemilik tanah bekas adat tersebut.

Tanah adat itu terbagi menjadi 2 yaitu Tanah Bekas Hak Milik Adat dan Tanah Milik Masyarakat Ulayat Hukum Adat. hukum tanah adat ini merupakan suatu hak kepemilikan dari penguasaan sebidang tanah yang mana ada didalam kehidupan masyarakat adat dimasa lampau maupun masa sekarang, baik itu yang memiliki bukti-bukti kepemilikan otentik atau secara tertulis yang mana berdasarkan pengakuan serta dan juga yang memiliki bukti otentik. Hukum tanah adat ini mencakup 2 jenis, yaitu hukum tanah adat masa lalu dan hukum tanah adat masa sekarang atau masa kini.

Penelitian ini difokuskan pada penelitian yang berkaitan dengan Tanah Bekas Hak Milik Adat. Tujuan penelitian ini adalah untuk mengetahui prosedur dari awal sampai akhir beserta persyaratan-persyaratan yang harus dilengkapi untuk mendaftarakan peralihan hak atas tanah bekas adat yang belum bersertifikat serta mengetahui permasalahan yang dihadapi oleh masyarakat Desa Ambit terkait dengan pendaftaran peralihan hak atas tanah bekas adat beserta solusi penyelesaiannya.

\footnotetext{
${ }^{1}$ Urip Santoso, “Penyelesaian Sengketa Dalam Pengadaan Tanah Untuk Kepentingan Umum,” Perspektif 21, no. 3 (2016): 188-98.

${ }^{2}$ Urip Santoso, Hukum Agraria Kajian Komprehensif (Jakarta: Kencana Prenada Media Group, 2012).
} 


\section{B. METODE PENELITIAN}

Metode penelitian yang digunakan adalah penelitian lapangan dengan menggunakan metode pendekatan yuridis empiris ${ }^{3}$ yang mana didalam penelitian ini didasarkan pada penelitian lapangan dan penelitian kepustakaan. Penggunaan metode penelitian hukum empiris ini disesuaikan dengan keadaan hukum yang dilakukan senyatanya. ${ }^{4}$ Kemudian dilanjutkan untuk menemukan fakta (fact-finding), penemuan masalah (problem-finding), setelah itu identifikasi masalah (problem-identification) dan terakhir penyelesaian masalah (problemsolution).

Penelitian ini menggunakan penulisan deskriptif dan menggunakan setting lokasi Desa Ambit Kecamatan Waled Kabupaten Cirebon dengan pengambilan data dari bahan hukum serta bahan kepustakaan berupa buku, jurnal, karya ilmiah, kamus dan perundang-undangan. Pengumpulan data dilakukan dengan wawancara untuk mendapat keterangan dari narasumber yaitu kepala desa serta studi dokumentasi dari kepustakaan, media cetak, media elektronik.

\section{HASIL DAN PEMBAHASAN}

\section{Pelaksanaan Pendaftaran Peralihan Hak Atas Tanah Bekas Adat Yang Belum Bersertifikat}

Peralihan hak atas tanah adalah proses berpindahnya hak kepemilikan atas bidang tanah dari pemegang hak sebelumnya kepada pemegang hak baru yang disebabkan karena suatu perbuatan hukum tertentu. Perbuatan hukum berpindahnya hak berupa tanah kepada pihak lain berlaku untuk selama-lamanya jika subyek hukumnya melengkapi syarat-syarat sebagai pemegang hak atas tanah sebagaimana ditentukan.

Peralihan hak atas tanah menurut yuridis dilaksanakan secara tertulis dengan akta yang dibuatkan oleh pejabat yang berwenang dan didaftarkan oleh Badan Pertanahan Nasional (Kantor Pertanahan Kab/Kota) dan langkah ini sangat berkaitan dengan mekanisme peralihan hak atas tanah, karena prosedur ini yang menentukan kebenaran peralihan hak atas tanah yang telah ditentukan berdasarkan syarat formil maupun materiil.

Masyarakat desa Ambit sejak dahulu sudah mengenal adanya peralihan hak atas tanah melalui adat karena pada saat itu belum berlakunya UUPA. Menurut pasal 37 ayat (1) Peraturan Pemerintah No. 24 Tahun 1997 Tentang Pendaftaran Tanah telah dijelaskan peralihan hak atas tanah dan hak milik atas satuan rumah itu dapat berupa jual beli, tukar menukar, hibah, pemasukan dalm perusahaan dan perbuatan hukum lainnya yang dapat mendaftarkan apabila membuktikan adanya akta yang sudah dibuat oleh PPAT yang berwenang sesuai dengan ketetapan peraturan perundang-undangan yang berlaku. ${ }^{5}$

Untuk memperoleh hak atas tanah wajib membuktikan dengan tanda bukti yang menguatkan sudah terjadi suatu perbuatan hukum, yang mana suatu perbuatan hukum yang

\footnotetext{
${ }^{3}$ Soerjono Soekanto, Pengantar Penelitian Hukum (Jakarta: UI-Press, 2014).

${ }^{4}$ Irwansyah, Penelitian Hukum: Pilihan Metode \& Praktik Penulisan Artikel, ed. Ahsan Yunus (Yogyakarta: Mirra Buana Media, 2020).

${ }^{5}$ I. W. Wiranegara, I. M. A., Wairocana, I. G. N., \& Wiryawan, "Tukar Menukar Hak Atas Tanah Antar Wilayah Oleh Pejabat Pembuat Akta Tanah," Acta Comitas: Jurnal Hukum Kenotariatan 2(2), no. Kenotariatan (2018): 213-18.
} 
berkaitan dengan pertanahan biasanya di buktikan oleh akta yang di keluarkan oleh Pejabat yang berwenang yakni Pejabat Pembuat Akta Tanah (PPAT) karena akta tersebut memiliki kekuatan hukum, agar dalam proses peralihan hak kepemilikannya bisa dilakukan, karena jika dalam memperoleh haknya itu tidak dibuktikan maka tidak memiliki kekuatan hukum, dan dalam proses peralihan haknya pun tidak bisa dilakukan karena dalam persyaratan-persayaratan yang wajib dipenuhi ketika proses peralihan hak atas tanah itu tidak terpenuhi. Salah satu perbuatan hukum yang berkaitan dengan pertanahan itu suatu perbuatan jual beli tanah, yang mana dalam proses peralihan hak kepemilikannya itu harus terdapat akta PPAT. ${ }^{6}$

Berdasarkan hasil penelitian lapangan ditemukan fakta Peralihan Hak Atas Tanah Bekas Adat yang sering terjadi di Desa Ambit hanya 3 (tiga) perbuatan hukum yaitu Peralihan Hak Atas Tanah Bekas Adat melalui jual beli, hibah dan waris. Sehingga peneliti memaparkan pelaksanaan peralihan hak atas tanah bekas adat yang terdiri dari sebagaimana berikut:

a. Peralihan Hak Atas Tanah bekas adat melalui Jual Beli Di Desa Ambit

Pada praktiknya peralihan hak atas tanah bekas adat (tanah yang belum bersertifikat) yang pada umumnya terjadi di Desa Ambit yakni melalui jual beli. Dalam pelaksanaannya jual beli tanah pada masyarakat Desa Ambit ini masih melaksanakan jual beli dengan berdasarkan hukum adat secara dibawah tangan yang mana persyaratannya harus memenuhi 3 unsur sebagai berikut: ${ }^{7}$

1) Secara tunai, yaitu pemberian hak oleh pihak penjual yang dilakukan secara serentak dengan pembayaran oleh pihak pembeli maka sejak itu juga hak telah beralih. Pembayaran harga yang dibayarkan tidak langsung lunas bisa dicicil tergantung dengan kesepakatan dari pihak penjual dan pembeli yang nantinya akan dianggap hutang oleh pembeli kepada penjual

2) Secara nyata, yang berarti atas kehendak yang sudah diucapkan oleh penjual dan pihak pembeli contohnya dengan diterimanya pembayaran oleh pihak penjual setelah itu dilanjutkan dengan dibuatkannya perjanjian ${ }^{8}$ yang disaksikan oleh kepala desa atau perangkat desa.

3) Secara terang atau konkrit yang mana dalam melakukan jual beli ini terjadi dihadapan kepala desa yang bertujuan meyakinkan perbuatan ini tidak menyimpang dari ketentuan yang berlaku.

Berikut proses peralihan hak atas tanah bekas adat melalui jual beli di desa Ambit: ${ }^{9}$

1) Langkah pertama, pihak pemohon menghadap ke Kantor Kelurahan untuk memperoleh surat keterangan bahwa tanah tersebut tidak dalam sengketa, surat keterangan riwayat tanah serta surat keterangan penguasaan tanah sporadik yang mana tiap-tiap dari surat keterangan dijelaskan sebagai berikut:

\footnotetext{
${ }^{6}$ B. D. Akbar, H. H. M., \& Lambok, “AKIBAT HUKUM PERALIHAN HAK ATAS TANAH BERDASARKAN SPPT PBB (Study Di Badan Pertanahan Naional Kabupaten Kuningan),” Hukum Responsif 10, no. 2 (2019): 4554.

7 Syukron, "Hasil Wawancara Dengan Syukron, Pada Tanggal 24 Februari 2021."

${ }^{8}$ Isdian Anggraeny and Sholahuddin Al-Fatih, "Kata Sepakat Dalam Perjanjian Dan Relevansinya Sebagai Upaya Pencegahan Wanprestasi," DE LEGA LATA: Jurnal Ilmu Hukum 5, no. 1 (2020): 57-66, https://doi.org/10.30596/dll.v5i1.3446.

${ }^{9}$ Syukron, "Hasil Wawancara Dengan Syukron, Pada Tanggal 24 Februari 2021."
} 
a) Surat Keterangan yang menyatakan bahwa tanah tidak ada sengketa yang mana nantinya akan ditandatangani oleh kepala desa setempat dan sebelum itu dari pihak kepala desa sendiri sudah memeriksa terlebih dahulu catatan perihal tanah dengan meneliti langsung kondisi tanah dilapangan. Jika terjadinya sengketa atas tanah tersebut maka pihak kepala desa atau lurah tidak mungkin memberikan surat keterangan hingga sengketa tanah tersebut diselesaikan. Surat keterangan tidak dalam sengketa ini disaksikan oleh saksi-saksi dari pihak yang dapat dipercaya yaitu baik dari pihak keluarga maupun pihak lurah setempat.

b) Surat Keterangan riwayat tanah ini berisikan secara urut dan tertulis penguasaan tanah dari mulai pertama pencatatan dikelurahan sampai dengan keadaannnya saat ini oleh pihak pemohon. Didalam surat keterangan riwayat tanah ini tercantum juga proses peralihannya guna kepemilikan tanah secara keseluruhan. Dan surat ini diajukan secara bersama-sama dengan surat keterangan tidak dalam sengketa

c) Surat keterangan Penguasaan Tanah adalah pencatatan tahun pemohon memiliki, menguasai serta memperoleh tanah tersebut. Yang mana dalam surat ini juga dibubuhi tanda tangan pemilik sah tanah tersebut guna untuk memperkuat kepemilikan tanah dan dalam lembar surat ini juga ditandatangani oleh pihak kepala desa atau lurah setempat yang berwenang. Surat keterangan ini dilampirkan bersama dengan dua surat sebelumnya.

2) Langkah kedua didalam proses jual beli tanah ini dari pihak pembeli wajib melengkapi syarat subjek dari tanah yang dibeli begitupun dengan pihak penjual wajib melengkapi syarat yakni memiliki wewenang memindahkan hak atas tanah yaitu berupa sebidang tanah dan dalam proses transaksinya disaksikan oleh kepala desa, adanya pencampuran atau kesaksian dari kepala desa merupakan faktor penting supaya lebih meyakinkan bahwa jual beli tanah tersebut adalah sah. Tetapi jika jual beli tanah itu tidak dilakukan dihadapan kepala desa bisa saja dianggap sah apabila syarat materiilnya telah terpenuhi oleh para pihak yaitu pihak pembeli yang sudah melakukan pembayaran kepada pihak penjual dengan begitu pihak penjual menyerahkan sepenuhnya hak atas tanah yang sudah dijual. ${ }^{10}$

Pada tanggal 23 Februari 2021 Langkah kedua didalam proses jual beli tanah ini dari pihak pembeli wajib melengkapi syarat subjek dari tanah yang dibeli dan begitupun dengan pihak penjual juga wajib melengkapi syarat yakni memiliki wewennang memindahkan hak atas tanah yaitu yang berupa sebidang tanah seluas $143 \mathrm{~m} 2$, terletak di Jalan/Blok Dusun manis Desa Ambit, Kecamatan Waled Kabupaten Cirebon yang merupakan tanah bekas milik adat sesuai Girik/petuk D/Letter C/Nop nomor 0177, Persil no. 008 yang penggunaannya berupa pekarangan dengan batas-batasnya:
a) Sebelah utara : Tanah milik $\mathrm{S}$
b) Sebelah Timur : Tanah milik NT/ER
c) Sebelah Selatan : Tanah milik D
d) Sebelah Barat : Tanah milik T-TR

${ }^{10}$ Syukron. 
Bahwa benar tanah itu milik SAR-CAR dan secara fisik dikuasai oleh yang bersangkutan

Bahwa riwayat tanah tersebut menurut catatan Buku Desa/Kelurahan Ambit adalah sebagai berikut:

a) Sebelum tahun 1960 tercatat pada girik/petuk D/Letter C.0177 atas nama KAS-RAS Persil no. 008 luas 104m2 NOP nomor 32.11.040.001.008.0177.0 yang kemudian tanah seluas $104 \mathrm{~m} 2$ dijual kepada ahliwaris dari W Cs dan D Cs berdasarkan dengan surat keterangan ahliwaris KAS tertanggal 5-5-2021 surat ket. ahliwaris RAS tertanggal 5-5-2021 dengan harga awal 7.400.000,-dan dengan harga akhir $5.000 .000,-$

b) Pada tahun 2020 sebagian tanah seluas $104 \mathrm{~m} 2$ selruhnya dijual kepada SAR-CAR berdasarkan Akta Jual Beli nomor 225 dengan harga awal 46.000.000,- dan dengan harga akhir 45.000.000,-

Dan dalam proses transaksinya disaksikan oleh KAR sebagai pihak dari kelurahan yang diharuskan sebab merupakan salah satu syarat mutlak oleh hukum adat dengan adanya pencampuran atau kesaksian dari kelurahan merupakan faktor penting supaya lebih meyakinkan bahwa jual beli tanah tersebut adalah sah. Tetapi jika jual beli tanah itu tidak dilakukan dihadapan kepala desa bisa saja dianggap sah apabila syarat materiilnya telah terpenuhi oleh para pihak yaitu pihak pembeli yang sudah melakukan pembayaran kepada pihak penjual dengan begitu pihak penjual menyerahkan sepenuhnya hak atas tanah yang sudah dijual. ${ }^{11}$

3) Langkah ketiga adalah dari pihak penjual dan pihakpembeli mendatangi PPAT untuk membuat Akta Jual Beli yang selanjutnya disingkat AJB yang mana akta ini merupakan bentuk legalitas hak dari pemberian status yang awalnya tanah girik. Pembuatan AJB disaksikan oleh Bapak KAR selaku pakubumi dari pihak kelurahan dan pembuatan AJB ini harus bersifat terang dan sudah dibayar dengan lunas. Dokumen-dokumen yang harus disiapkan ketika ingin membuat AJB sebagaimana berikut. Dokumen yang wajib disiapkan pihak penjual:

a) Fotocopy KTP (Kartu Tanda Penduduk) dari pihak penjual suami/istri (apabila salah satu dari istri/suami penjual telah meninggal maka disertakan surat keterangan kematian)

b) Fotocopy Kartu Keluarga (KK)

c) Bukti Pembayaran Pajak Bumi dan Bangunan (PBB) tahun terakhir

d) Fotocopy NPWP (jika ada)

Dokumen yang wajib disiapkan pihak pembeli:

a) Fotocopy KTP (Kartu Tanda Penduduk)

b) Fotocopy Kartu Keluarga (KK)

c) Fotocopy surat menikah (jika sudah menikah)

d) Fotocopy NPWP (jika ada)

${ }^{11}$ Syukron. 
Berdasarkan uraian diatas dapat dilihat pada bagan sebagaimana berikut:

Bagan 1. Prosedur peralihan Hak Atas Tanah bekas adat yang belum bersertifikat Melalui Jual Beli (Sumber: Data diolah oleh penulis. 2021)

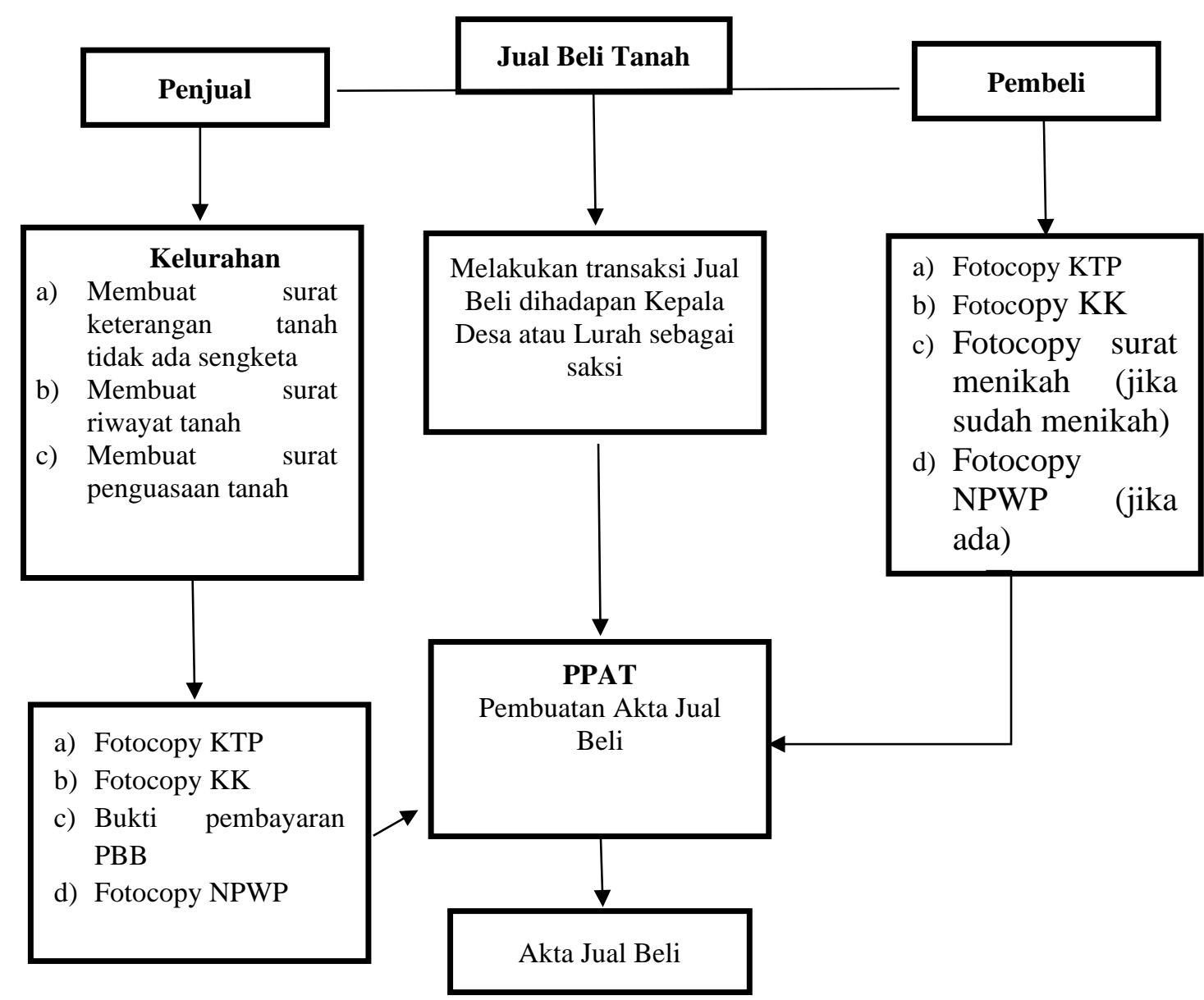




\section{b. Peralihan Hak Atas Tanah bekas adat melalui Hibah Di Desa Ambit}

Peralihan hak atas tanah bekas adat selanjutnya yang sering dijumpai masyarakat desa Ambit yaitu Peralihan hak atas tanah melalui Hibah. Menurut pasal 1666 ayat 1 KUHPerdata menyatakan bahwa Hibah yaitu suatu persetujuan yang mana orang yang menghibahkan memberikan secara cuma-cuma kepada penerima hibah guna keperluannya dan tidak bisa ditarik kembali atas pemberian tersebut. Dalam pelaksanaanya perbuatan hukum berupa hibah ini dapat sah secara hukum apabila memenuhi ketetapan Pasal 1320 KUHPerdata yaitu: 1) terjalinnya kesepakatan para pihak (yakni pihak pemberi hibah dan penerima hibah) 2) adanya obyek tertentu (dalam hibah ini yakni berupa hak atas tanah). ${ }^{12}$ Pelaksanaan hibah pada masyarakat desa Ambit ini dilakukan secara adat dengan cara dibawah tangan atau dikatakan secara lisan dan dianggap sah karena perbuatannya nyata yang dalam hal ini berupa pemberian suatu hak yaitu tanah yang menjadi obyek hibah.

Dan berikut prosedur peralihan hak atas tanah bekas adat melalui hibah di desa Ambit sebagaimana berikut:

1) Langkah pertama, dalam prosesnya peralihan hak atas tanah bekas adat melalui hibah ini DUL sebagai Pemberi hibah harus mempunyai kewenangan untuk memindahkan hak kepada ESFsebagai penerima hibah berupa tanah sebidang tanah seluas $205 \mathrm{~m} 2$, yang terletak dijalan/ Blok Pesantren Desa Ambit Kecamatan Waled, Kabupaten Cirebon adalah tanah bekas adat yang sesuai dengan Girik/petuk D/Letter C/Nop nomor 984, Persil no. 136 Klas D.I yang fungsinya berupa tempat tinggal, dengan batasbatasnya:
a. Sebelah utara : Tanah MUS
b. Sebelah Timur : Tanah milik DULK
c. Sebelah Selatan : Tanah milik PR
d. Sebelah Barat : Tanah milik RT

Riwayat tanah tersebut berdasarakan catatan buku desa/ kelurahan Ambit sebelum tahun 1960 tercatat pada Girik/ Petuk D/ Letter C.984 atas nama HAS dengan No. Persil 136 Klas D.I Luas 205 m2 dan kemudian dijual kepada DUL

2) Langkah kedua, pihak pemberi hibah dan pihak penerima hibah menghadap kepada Kepala Desa atau lurah untuk memberikan keterangan yang mana sebagai beriku:

a) Bahwa tanah itu bukan Aset pemerintah atau pihak lain dan tidak termasuk dalam wilayah hutan

b) Bahwa tanah itu tidak sedang menjadi jaminan suatu hutang dan tidak dalam sengketa dengan pihak lain, baik itu luas, batas-batas maupun penguasaanya

c) Bahwa tanah tersebut adalah tanah hak milik adat

d) Bahwa tanah tersebut belum dimohon sesuatu hak kepada instansi yang berwenang

3) Langkah ketiga, Kepala Desa mengesahkan dan mencatat pada buku desa bahwa adanya perbuatan hukum yaitu peralihan hak atas tanah melalui hibah

12 I. Maryuningrum, V. P., Triwahyudi, P., \& Darori, "Efektifitas Hibah Hak Atas Tanah Menurut Hukum Adat Dalam Pendaftaran Tanah Di Kabupaten Boyolali," (Doctoral Dissertation, Sebelas Maret University)., 2017, 96104. 
4) Langkah keempat dalam pelaksanaannya disaksikan oleh saksi yaitu dari pihak keluarga pemberi hibah maupun penerima hibah dan pihak kelurahan yakni Kepala Desa

5) Langkah kelima, dalam pengurusannya pihak pemberi hibah dan penerima hibah menyerahkan kepada Kepala Desa

6) Langkah keenam, adanya kerja sama antara Kepala Desa dan PPAT. Kepala Desa mengantarkan para pihak dari pemberi dan penerima hibah kepada PPAT setempat. Karena perbuatan hukum peralihan hak atas tanah ini harus didaftarkan guna mendapatkan kepastian hukum dengan dibuatkannya pendaftaran peralihan hak atas tanah berupa akta hibah oleh PPAT dan disaksikan oleh pihak-pihak yang berhak. Dalam proses ini penghibah dan penerima hibah serta ahli waris diwajibkan harus hadir dihadapan PPAT jika tidak bisa maka harus dibuatkannya surat kuasa.

Dan berdasarkan hasil penelitian penulis dengan melakukan wawancara, bahwasannya dalam pelaksanaannya peralihan hak atas tanah melalui hibah harus melengkapi beberapa dokumen sebagai berikut: ${ }^{13}$

1) Fotocopy KTP dan KK dari pemberi dan penerima hibah

2) Surat Pemberitahuan Objek Pajak Bumi dan Bangunan (SPOP PBB)

3) Surat Keterangan Tanah Bekas Milik Adat yang sesuai dengan Girik/ petuk D/ letter C serta Nomor Persil dikeluarkan oleh kelurahan

4) Surat Pernyataan perjanjian keduabelah pihak yang diketahui oleh kepala desa sebgai saksi

${ }^{13}$ Syukron, "Hasil Wawancara Dengan Syukron, Pada Tanggal 24 Februari 2021.”, 
ILREJ, Vol. 1, No. 2, Juli 2021

Berdasarkan uraian diatas dapat dilihat pada bagan sebagaimana berikut:

Bagan 2. prosedur peralihan hak atas tanah bekas adat yang belum bersertifikat melalui Hibah (Sumber: Data diolah oleh penulis. 2021)

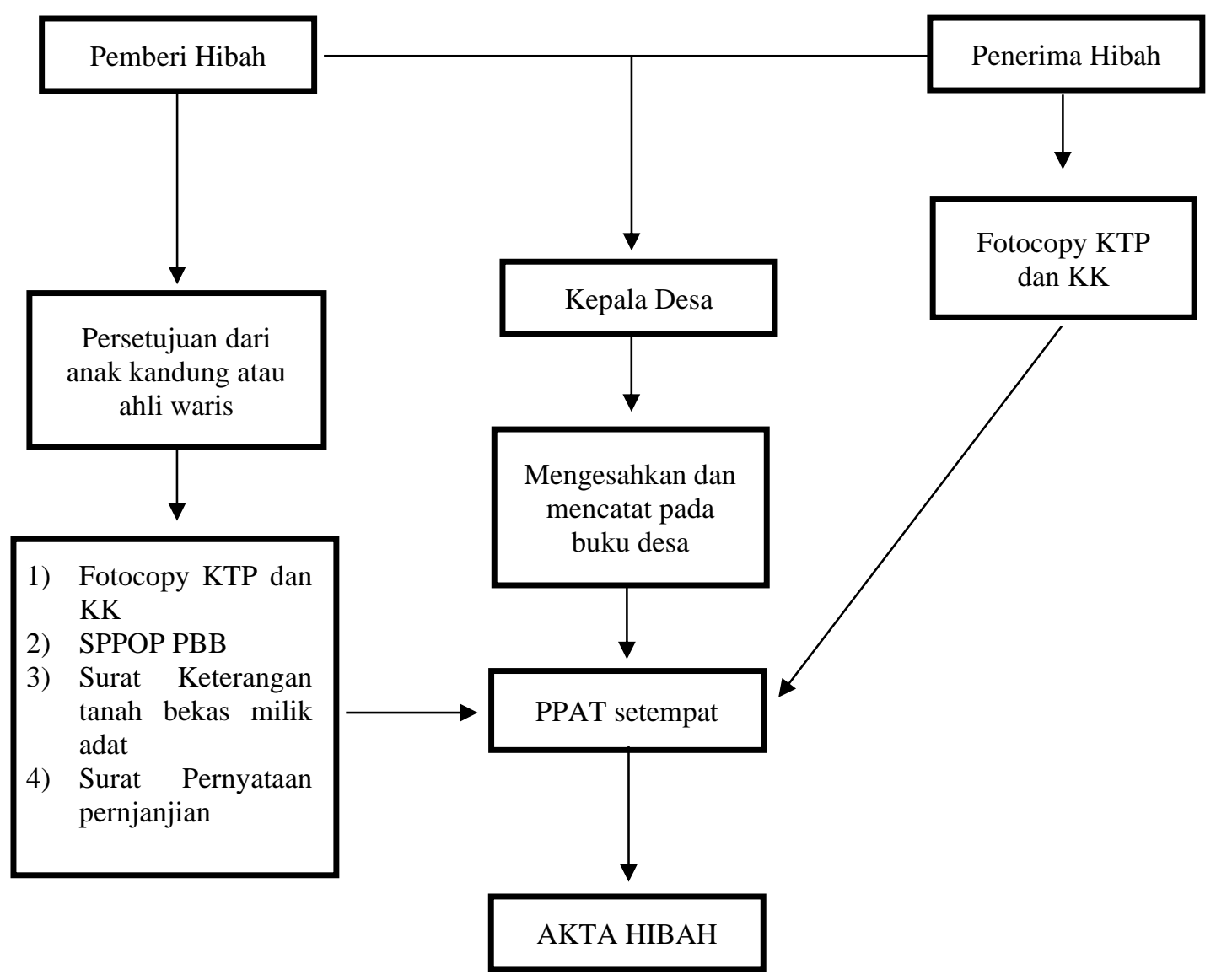




\section{c. Peralihan Hak Atas Tanah Bekas Adat Melalui Pewarisan di Desa Ambit}

Peralihan hak atas tanah bekas adat di desa Ambit selajutnya adalah melalui perbuatan hukum yaitu waris. Didalam peralihan hak atas tanah melalui waris ini dilakukan sebelum pewarisnya meninggal dunia. Maka secara adat hak seseorang akan beralih sendirinya kepada ahli waris. Dan pewarisan akan terjadi apabila melengkapi 3 syarat yakni sebagai berikut: 1) Adanya seseorang yang telah meninggal dunia 2) Adanya seorang yang masih hidup sebagai ahli waris; 3) obyek harta kekayaan yang ditingglkan oleh pewaris. Karena di desa Ambit merupakan peralihan hak atas tanah bekas adat yang belum bersertifikat maka tanah warisan yang belum didaftar maka wajib menyerahkan dokumen-dokumen sebagaimana telah diatur pada pasal 39 ayat (1) PP Pendaftaran Tanah Nomor 24 Tahun 1997 yaitu:

Surat bukti hak yang mana sudah dijelaskan pada pasal 24 ayat 1 atau surat keterangan dari kelurahan yang berisikan bahwa yang pemegang hak menempati bidang tanah itu dan sebagaimana yang sesuai paasal 24 ayat (2) Surat Keterangan yang menyatkan bahwa bidang tanah tersebut belum terdaftart. ${ }^{14}$ Salah satu syarat awal untuk pendftaran peralihan hak milik atas tanah karena pewarisan yaitu melampirkan surat keterangn waris yang dikuatkan oleh lurah setempat. Berdasarkan ketetapan terkait peralihan hak milik atas tanah disebabkan pewarian diatur padaPasal 61 ayat (1) Peraturan Pemerintah Nomor 24 Tahun 1997 merupakan kewajiban untuk didaftarkan oleh ahli waris pada kantor pertanahan. Jika pada jangka waktu 6 bulan sejak tangal tiadanya pewaris terkait pendaftaran peralihan hak milik atas tanah karena pewarisan tidak dipungut biaya pendaftaran.

Biasanya masyarakat desa Ambit untuk menghitung hubungan dari keturunan biasanya pewaris ini berdasarkan dengan garis keturunan dari atas (orang tua pewaris), garis keturunan samping (saudara dsb) dan garis keturunan bawah (anak dan cucu). Dalam proses peralihannya sebagaimana berikut: ${ }^{15}$

Pada tanggal 5 Mei 2021, dibuatkan surat keterangan ahliwaris yang berisikan keterangan yang menyatakan bahwa Almarhum RAS yang meninggal pada 1986 di Desa Ambit Kec. Waled Kab. Cirebon dan semasa hidupnya almarhum menikah dengan KT yang sudah meninggal pada tahun 1999 di Desa Ambit kec. Waled Kab. Cirebon dan dari perkawinannya dikarunia 4 orang anak kandung yang sampai sekrang masih hidup dan mewariskan sebidang tanah seluas 600m2 yang terletak dijalan/Blok Pahing Desa Ambit Kecamatan Waled, Kabupaten Cirebon adalah tanah bekas adat yang sesuai dengan Girik/petuk D/Letter C/Nop nomor 236, Persil no. 124 Klas D.I yang berupa tanah sawah dengan batas-batasnya:
a. Sebelah Utara
: Tanah milik MAK
b. Sebelah Selatan
: Tanah milik NI
c. Sebelah Timur
: Jalan
d. Sebelah Barat
: Tanah milik AD

RAS-KT selaku pewaris menetapkan ahli waris dengan membagikan harta ahli waris itu kepada keempat anak kandungnya yakni sebagaimana berikut:

1) Kepada D seluas $100 \mathrm{~m} 2$ selaku anak pertama

${ }^{14}$ C. F. Lamia, "Peralihan Hak Atas Tanah Warisan," Lex Privatum 2, no. 3 (2014).

${ }^{15}$ Syukron, "Hasil Wawancara Dengan Syukron, Pada Tanggal 24 Februari 2021." 
2) Kepada DAS seluas $100 \mathrm{~m} 2$ selaku anak kedua

3) Kepada MUL seluas 300m2 selaku anak ketiga

4) Kepada CSH seluas $100 \mathrm{~m} 2$ selaku anak keempat

Dalam proses ini disaksikan oleh Pakubumi desa, Kepala Desa serta sesepuh desa, setelah itu dibuatkannya surat keterangan waris oleh kelurahan setempat dan pihak kelurahan juga membuat Surat Riwayat Tanah yang menyatakan bahwa tanah tersebut selama dipegang oleh pewaris tidak pernah ada sengketa dan melampirkan kutipan Letter C desa yang sudah dilegalisir oleh kepala desa kemudian Pakubumi Desa mengantarkan pihak yang bersangkutan ke PPAT yang selanjutnya oleh PPAT akan dibuatkan Akta pembagian hak bersama.

Berdasarkan uraian diatas dapat dilihat pada bagan sebagaimana berikut:

Bagan 3. prosedur peralihan hak atas tanah bekas adat yang belum bersertifikat melalui pewarisan (Sumber: Data diolah oleh penulis. 2021)

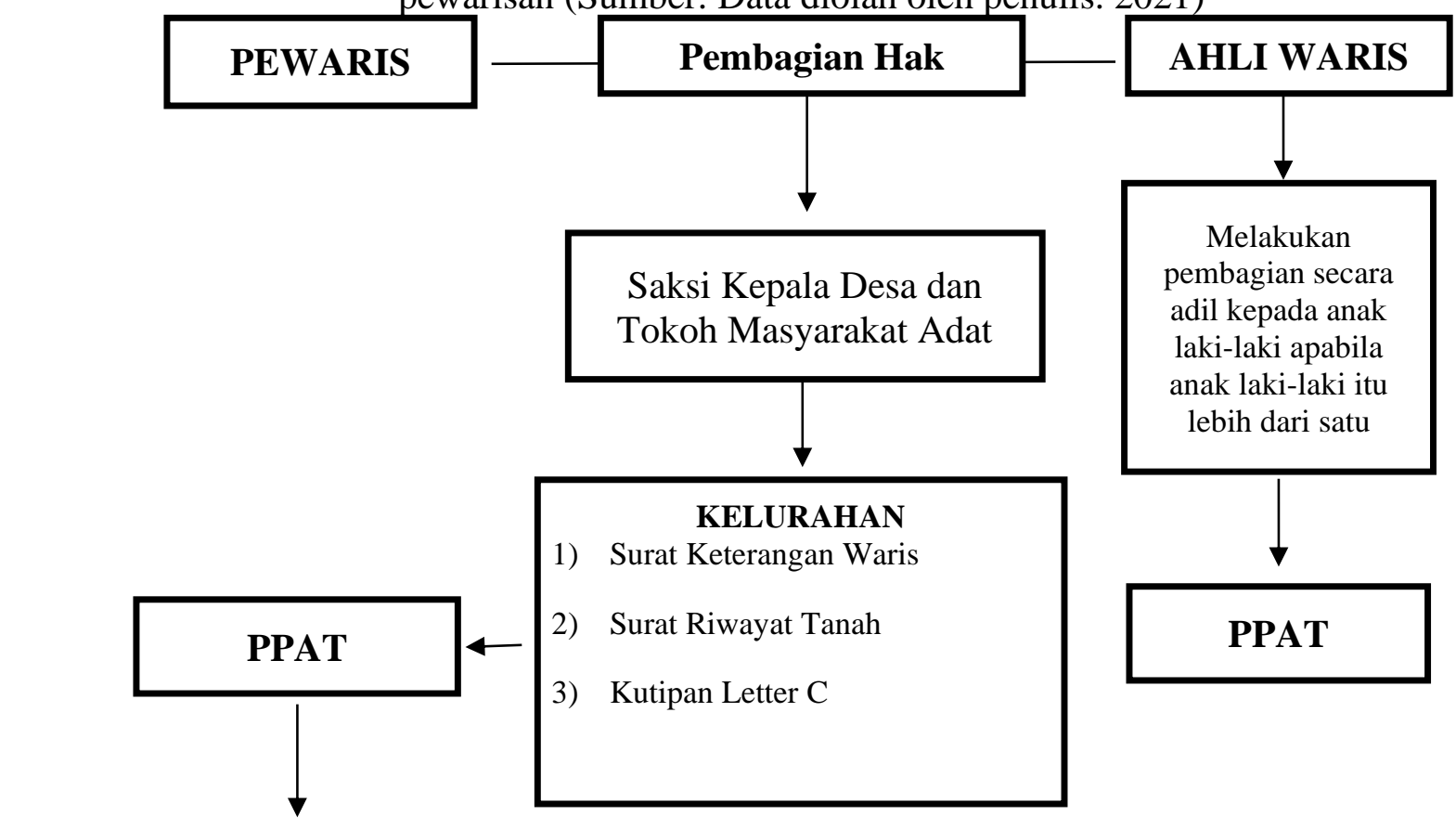

\section{AKTA PEMBAGIAN HAK}


Pelaksanaan pendaftaran peralihan hak atas tanah bekas adat yang belum bersertifikat didesa Ambit telah sesuai berdsarkan ketentuan yang telah ditetapkan pada Pasal 37 ayat 1 PP Nomor 24 Tahun 1997 Tentang Pendaftaran Tanah yang telah tercantum setiap hak atas tanah yang dialihkan dan karena pemindahan hak lainnya maka wajib dibuktikan dengan Akta yang telah dibuat oleh PPAT. Sebagai alat bukti bahwa sudah dilakukannya perbuatan hukum yang kemudian akan dijadikan dasar perubahan data pendaftaran tanah. Untuk syarat yang menyatakan akta itu harus dibuat oleh pejabat umum yang memiliki kewenangan untuk menerbitkan akta, ditegaska pada Pasal 4 ayat (1) Peraturan Pemerintah Nomor 37 Tahun1998 yang menyatakan bahwa "PPAT mempunyai kewenangan untuk membuat akta mengenai hak atas tanah atau hak milik atas satuan rumah susun yang terdapat di lingkup daerah kerjanya".

Sebagaimana pada pasal 38 ayat (1) juga menjelaskan bahwa dalam melakukan perbuatan hukum harus dihadiri oleh pihak yang bersangkutan berikut dengan saksi-saksi yang memenuhi persyaratan sebagai saksi dalam perbuatan hukum. Selain itu berdasarkan pasal 39 ayat (1) huruf b PP Pendaftaran Tanah Nomor 24 Tahun 1997 dalam pendaftarannya prosesnya pihak-pihak yang bersangkutan wajib menyerahkan dokumen-dokumen sebagaimana berikut yakni:

1) Surat bukti hak sebagaimana sudah dijelaskan pada pasal 24 ayat (1) mengenai surat keterangan yang dikeluarkan oleh Kepala Desa atau kelurahan yang berisikan bahwa yang bersangkutan menempati bidang tanah itu dengan dibuktikannya dengan alat-alat bukti mengenai adanya hak yakni melipputi bukti-bukti tertulis, keterangan saksi dan pernyataan dari pihak yang bersangkutan dan sebagaimana yang dimaksud pasal 24 ayat (2) jika alat-alat pembuktian tidak lengkap maka dibuktikan dengan pembukuan hak yang sesuai dengan kenyataan penguasaan fisik bidang tanah selama 20 tahun atau bahkan lebih.

2) Surat Keterangan yang berisikan mngenai bidang tanah tersebut belum terdafatar dari pemegang hak yang bersangkutan dengan dibenarkan oleh kepala desa ataukelurahan.

3) Surat keterangan yang berisikan bahwa tanah tersebut belum terdaftar oleh kantor pertanahan tapi apabila tanah tersebut terdapat didaerah yang tidak terjangkau dari Kantor Pertanahan maka dikuatkan oleh lurah setempat. Maka lurah yang berperan penting terkait dengan proses peralihan hak atas tanah. Selain itu sebagai kepala desa merupakan seorang yang paham kondisi dan status tanah.

Begitu peralihan hak atas tanah bekas adat yang belum bersertifikat pada dasarnya mempunyai kekuatan hukum yang setara dengn tanah yang sudah bersertifikat karena berdasarkan ketentuan PP No. 24 Tahun 1997 menyatakan bahwa peralihan hak atas tanah yang belum terdaftar atau belum didaftarkan oleh pemilik tanah sebelumnya dapat dialihkan hak kepemilikannya dengan syarat bahwa pemilik tanah sebelumnya dapat memberikan bukti-bukti kepemilikan tanah yang berupa Letter C, Girik dan surat keterangan terkait kadar kebenaran kepemilikan dari pemilik tanah. Namun untuk menjamin kepastian hukum atas peralihan ha katas tanah dari pihak pemegang sebelumnya kepada pemegang hak yang baru dalam prosesnya harus dilakukan dihadapan PPAT yang selanjutnya nanti menjadi dasar acuan oleh Badan Pertanahan Nasional ntuk diterbitkannya sertifikat hak milik. 
Terkait peralihan hak atas tanah bekas adat yang belum bersertifikat itu tidak daftarakan di kantor pertanahan maka akan menimbulkan akibat hukum. Akibat hukum berkenaan dengan peralihan hak atas tanah yang belum bersertifikat adalah dapat sah secara hukum jika peralihan hak atas tanah tersebut sudah memenuhi syarat materiil yang mana hak dan kewajiban pemegang hak sebelumnya ini langsung beralih kepada pemegang hak yang baru akan tetapi peralihan hak atas tanah bekas adat yang belum bersertifikat ini memunculkan akibat hukum yang lain yakni bagi pihak pemegang hak atas tanah sebab tidak ada jaminan kepastian hukum yang sinkron dengan tujuan pendaftaran yakni untuk menjamin kepastian hukum dan kepastian hak atas tanah yang mana pada dasarnya terdaftrnya hak kepemilikan atas tanah seseorang dibuktikan dengan diterbitkannya tanda bukti kepemilikan berupa sertifikat hak atas tanah, dalam hal ini negara pasti memberikan jaminan hukum terhdap pemilik tanah tetapi sebaliknya jika tanah-tanah tidak didaftarkan maka negara tidak dapat menjamin kepastian hukum kepada pemilik tanah dalam hal ini hanya menguasai secara fisik namun tidak dapat membuktikan kepemilikannya secara yuridis sebagaimana telah diatur didalam pasal 19 UUPA dan PP Pendaftaran Tanah No. 24 Tahun 1997.

Berdasarkan hasil dari penelitian adapun faktor-faktor yang mempengaruhi tidak dilakukannya pendaftaran oleh para pihak, antara lain:

1) Para pihak kurang paham akan fungsi serta kegunaan sertifikat

Para pihak masih belum memahami fungsi serta kegunaan sertifikat Karena kurangnya pengetahuan ini menyebabkan kurangnya akan kesadaran masyarakat untuk mendaftarkan tanahnya. Dan para pihak beranggapan bahwa sertifikat hak atas tanah hanya dilhat dari segi ekonomis yaitu sebagaimana berikut:

a) Masyarakat beranggapan sertifikat hanya dibutuhkan untuk menaikkan harga dari bidang tanah sebagai pembayaran dari biaya pengurusan sertifikat ke kantor pertanahan, padahal sebenarnya harga ekonomis suatu bidang tanah dinilai berdasarkan luas dan kuaalitas tanahnya

b) Para pihak menganggap sertifikat dibutuhkan pada saat mengajukan pinjaman di bank sebagai agunan pemberian kredit yang akan dijadikan sebagai obyek hak tanggungan.

2) Para pihak menganggap bahwa dibutuhkan biaya yang mahal

Dalam melaksanakan Pendaftaran Tanah di desa Ambit kemungkinan diadakannya tarif terkait pendftaran tanah untuk setiap kegiatan Pendaftaran Tanah sesuai dengan ketentuan PP No. 46 Tahun 2002 namun dalam praktiknya dari pihak instansi pertanahan ataupun pemerintah pada tingkat daerah terkecil seperti Kepala Desa, Lurah Camat perihal penerbitan alas hak tetap dilakukanya pengkutipan di luar ketetapan yang berlaku.pada kenyataannya pendaftaran tanah di desa Ambit dilaksanakan secara sporadik dengan biaya yang cukup besar yang berdampak pelaksanaan pendaftaran tanah di desa Ambit tidak berlangsung dengan baik dan masyarakat kurang mendapat informasi terkait pendaftaran tanah ternyta tingkat pendidikan yang juga mempengaruhi kesadaran masyarakat terkait mendaftarkan tanahnya dan juga dipengaruhi oleh anggapan para pihakt bahwa pendaftaran tanah diperlukan biaya yang mahal.

3) Para pihak menganggap bahwa dalam pengurusan sertifkat dibutuhkan waktu yang lama 
Para pihak menganggap dalam pengurusan sertifikat hak atas tanah memerlukan waktu yang lama. Sesuai yang telah dijelaskan oleh pihak camat bahwa dalam pendafatran tanahnya yang dilakukan secara sporadik diketahui membutuhkan jangka waktu proses pembuatan sertifikat paling cepat 3 sampai 4 bulan dan paling lama 8 bulan namun ada juga yng prosenya sampai 1 tahun baru selesai.

4) Para pihak menganggap bahwa alat bukti alas hak tanah yang dimiliki sudah kuat Berdasarkan hasil penelitian senyatnya para pihak kurang mengetahui kegunaan sertifikat karena para pihak menganggap tanah-tanah yang telah didaftarkan itu sudah bersurat maupun surat apapun namanya dan siapa yang menerbitkan asal dalam dibuatkan oleh instansi Pemerintah yang berarti tanah tudah didaftar dan terdapat alat bukti hak yang kuat terlebih lagi jika tanah yang didapatkan dari hasil pewarisan biasanya masyarakat mengetahui mengenai riwayat pemilik tanah sebelumnya.

\section{d. Bentuk Permasalahan Yang Dialami Oleh Masyarakat Desa Ambit dalam pendaftaran peralihan hak atas tanah bekas adat yang belum bersertifikat dan Solusinya}

Sertifikat hak atas tanah berfungsi sebgai alat bukti kepemilikan suatu hak atas tanah kepada pemegang hak atas tanah yang bersngkutan. Yang mana ini mengartikan bahwa Sertifikat atas tanah di terbitkan guna keperluan pihak pemegang hak atas tanah sebagaimana telah tercantum didalam Pasal 31 ayat 1 PP Pendaftaran Tanah Nomor 24 Tahun 1997. Dalam Pasal 32 PP Pendaftaran Tanah Nomor 24 Tahun 1997 yang menyatakan "Sertifikat hak atas tanah adalah surat tanda bukti hak yang berguna sebagai alat pembuktian yng kuat terkait data fisik dan data yuridis yang temasuk di dalamnya selagi data fisik dan data yuridis telah sesuai dengan data yang ada di dalam surat ukur dan buku tanah hak yang bersangkutan. Dengan didaftarakannya bidang tanah pada hakikatnya akan menjamin jaminan keamanan akan kepemilikanya dalam mewujudkan kepastian hukum terlebih seorang pemilik akan mendapatkan kesempurnaan dari haknya. ${ }^{16}$

Kepastian hukum didalam pendaftaran tanah memiliki tujuan demi tercapainya perlindungan hukum kepada pemegang hak atas tanah, maka karena itu jika timbulnya permasalahan dalam sengketa yang bergantian di pengadilan maka wajib diadakannya pembuktian. Maka dari itu para pihak yang bersengketa membutuhkn alat bukti serta sertifikat yang merupakan hasil dari proses pendaftaran tanah. Pendaftaran Tanah bertujuan memberikan jaminan kepastian hukum yang biasanya disebut dengan sebutan Rechts Cadaster. Adanya jaminan kepastian hukum yang akan dimasukkan ke dalam pendaftaran tanah ini kepastian status hak yang telah di daftar, kepastian subyek hak serta kepastian obyek hak sehingga pendaftaran ini membuahkan hasil yang berupa sertifikat sebagai tanda bukti haknya. ${ }^{17}$

Pada praktiknya, di Desa Ambit peralihan hak atas atas tanah itu hanya cukup sampai akta auttentik yang dibuat oleh PPAT. Akta memang memiliki kekuatan hukum, namun untuk pembuktian terkuat terkait kepemilkan atas tanah dibuktikan dengan adanya surat tanda bukti hak yang berupa sertifikat. Untuk itu, sebaiknya dilakukan pengurusan sertifikat

${ }^{16}$ Adrian Sutedi, Sertifikat Hak Atas Tanah (Jakarta: Sinar Grafika, 2012).

${ }^{17}$ Urip Santoso, Pendaftaran Dan Peralihan Hak Atas Tanah (Jakarta: Kencana Prenada Media Group, 2010). 
tanah agar jika terjadi sengketa (semisal: tanah yng dikuasiai secara fisik oleh pihak lain), pemilik tanah memiliki dasar kepemilikan yang kuat.

Namun dalam proses pendaftaran peralihan hak atas tanah terdapat beberapa permasalahan yang timbul, yaitu:

1. Bidang tanah dalam proses pendaftaran yang masih dalam keadaan sengketa. Sengketa tersebut meliputi:

a. Adanya sengketa waris.

Dalam praktiknya permasalahan yang timbul dalam proses pendaftaran tanah yang terjadi didesa Ambit yaitu adanya sengketa waris misalnya ada pemohon mengajukan 15 ahli waris namun ternyata ada 2 orang ahli waris yang keberadaannya tidak diakui mengajukan surat keberatan bahwa 2 ahli waris tersebut belum melakukan penandatanganan padahal semestinya 2 orang ahli waris tersebut mempunyai hak untuk menandatangani sebagai bagian dari ahli waris tersebut. ${ }^{18}$

Karena tanpa tanda tangan semua ahli waris bahkan jika minimal dari satu ahli waris itu tidak menandatanganinya, maka dalam hal ini tentunya sebagian ahli waris berhak sepenuhnya mengenai hak atas tanah tersebut. Sebab tidak semua tanah itu melekat pada hak nya yakni 15 orang ahli waris tadi, tetapi 2 orang ahli waris ini juga mempunyai hak atas tanah. Walaupun dilakukan dengan Akta PPAT tetapi karena kurang ada persetujuan atau tanda tangan salah satu ahli warisnya, maka Akta yang dibuatkan oleh PPAT tersebut akanbatal demi hukum. Meskipun dalam prakteknya dapat dikembalikan kepada para pihak baik antara ahli waris maupun salah satu ahli waris. ${ }^{19}$

b. Adanya sengketa batas

Dalam permasalahan proses pendaftaran yang terjadi di Desa Ambit terkait sengketa batas yaitu pada saat pemohon menyerahkan terkait data-data dan administrasi batas/wilayah tanah tidak sesuai dengan data yang diperoleh saat melakukan pengukuran terkait batas tersebut. Yang mana pada saat melakukan pengukuran dan pemetaan terdapat pihak (tetangga) yang tidak menyetujui data wilayah tanah yang diberikan oleh pemohon. Tidak ada kejelasan terkait dengan batas tanah ini dipengaruhi oleh pergantian batas tanah secara sepihak yakni terjadi selisih pendapat, nilai kepentingan terkait letakbatas serta luas bidang tanah yang diakui satu pihak.

c. Adanya sengketa kepemilikan

Permasalahan yang terjadi didesa Ambit terkait dengan sengketa kepemilikan yaitu pihak yang merasa tanah tersebut miliknya namun tidak menguasai tanah secara fisik, yang menyebabkan peguasaan kepemilikan tanah secara fisik merasa tanah tersebut miliknya. Sehingga mengakibatkan satu bidang tanah yang di klaim oleh dua subyek. ${ }^{20}$

${ }^{18}$ David, "Hasil Wawancara Dengan David Selaku Kepala Bidang Pengkajian Dan Penanganan Sengketa Dan Konflik Pertanahan, Pada Tanggal 23 Februari 2021.”

${ }^{19}$ Y. P. Anggraeny, I., \& Pramithasari, "Legal Review of Selling Land of Inheritance without Approval of All Heirs," Legality 28, no. 1 (2020): 107-20.

${ }^{20}$ David, "Hasil Wawancara Dengan David Selaku Kepala Bidang Pengkajian Dan Penanganan Sengketa Dan Konflik Pertanahan, Pada Tanggal 23 Februari 2021.” 


\section{Tidak ada bukti pembayaran SPPT PBB}

Permasalahan yang sering terjadi didesa Ambit terkait dengan proses pendaftaran peralihan hak atas tanah tanah yakni masyarakat yang akan mendaftarkan tanahnya tidak memilik bukti pembayaran dari pemilik sebelumnya. Hal ini mengakibatkan proses pendaftaran peralhan hak atas tanah oleh pemohon menjadi terhambat karena salah satu syarat yang harus dipenuhi dalam pendaftaran peralihan hakatas tanah yaitu melampirkan foto copy SPPT PBB yang telah dibayar lunas maksimal 5 (lima) tahun terakhir. Sehingga apabila SPPT PBB belum dibayar lunas oleh pemilik sebelumnya maka pomohon yakni pembeli tidak bisa mendaftarkan tanahnya.

Pada dasarnya dalam pelaksanaannya terdapat suatu masalah maka dari itu dalam menangani permasalahan dalam kegiatan pendaftaran peralihan hak atas tanah bekas adat didesa Ambit maka perlu diadakannya upaya-upaya untuk memberikan solusi yang tepat sehingga dalam pelaksanaan pendaftarannya sesuai dengan kebijakan peraturan perundangundangan. Dilihat dari permasalahan diatas maka penulis memberikan solusi berupa:

1) Dilakukan mediasi diantara kedua belah pihak untuk mencapai suatu kesepakatan yang mana dalam prosesnya dihadiri dengan minimal 2 orang saksi yaitu kepala desa dan PPAT sementara. Namun apabila dalam mediasi tersebut tidak mencapai kesepakatan maka diserahkan kepada Pengadilan. Setelah itu pengadilan menyerahkan kepada pihak BPN terkait dengan putusannya dan BPN menindaklanjuti putusan tersebut.

2) Kelurahan desa Ambit lebih memperhatikan terkait pajak dengan mengadakan sosialisasi minimal diadakan dalam 1 tahun sekali tentang pentingnya wajib pajak sehingga pada saat proses pendaftaran peralhan hak atas tanah tidak terjadi permasalahan terkait belum lunasnya SPPT PBB.

\section{PENUTUP}

\section{Kesimpulan}

Pelaksanaan pendaftaran peralihan hak atas tanah bekas adat yang belum bersertifikat di Desa Ambit telah dilaksanakan sesuai dengan ketentuan peraturan pemerintah pendaftaran tanah No. 24 Tahun 1997. Peralihan hak atas tanah di desa Ambit dilakukan dengan 3 perbuatan hukum yaitu peralihan hak atas tanah bekas adat melalui jual beli, hibah dan waris. Terdapat beberapa permasalahan yang timbul dalam proses pendaftaran peralihan hak atas tanah bekas adat yang belum bersertifikat seperti bidang tanah masih dalam keadaan sengketa (sengketa waris, batas dan kepemilikan) sehingga diperlukan mediasi kedua belah pihak. Selanjutnya, tidak ada bukti pembayaran SPPT PBB dari pemilik sebelumnya sehingga kesulitan mendaftarkan tanahnya sehingga perlu sosialisasi wajib pajak agar tidak ada permasalahan terkait belum lunasnya SPPT PBB.

\section{Saran}


Masyarakat terutama pihak pemegang hak atas tanah wajib mengikuti prosedur yang ditetapkan oleh Peraturan Pemerintah Pendaftaran Tanah No. 24 Tahun 1997 ketika hendak mengajukan persyaratan pendaftaran peralihan hak atas tanah. Seluruh bentuk peralihan semestinya didaftarkan dengan teliti memenuhi persyaratan untuk membantu kinerja pejabat yang berwenang. Serta dilakukannya penyuluhan wajib pajak secara berkala sebagai pengingat tenggat waktu pembayaran pajak dan meminimalisir proses pendaftaran peralihan hak atas tanah di desa Ambit.

\section{E. DAFTAR PUSTAKA}

Akbar, H. H. M., \& Lambok, B. D. “AKIBAT HUKUM PERALIHAN HAK ATAS TANAH BERDASARKAN SPPT PBB (Study Di Badan Pertanahan Naional Kabupaten Kuningan)." Hukum Responsif 10, no. 2 (2019): 45-54.

Anggraeny, I., \& Pramithasari, Y. P. "Legal Review of Selling Land of Inheritance without Approval of All Heirs." Legality 28, no. 1 (2020): 107-20.

Anggraeny, Isdian, and Sholahuddin Al-Fatih. "Kata Sepakat Dalam Perjanjian Dan Relevansinya Sebagai Upaya Pencegahan Wanprestasi." DE LEGA LATA: Jurnal Ilmu Hukum 5, no. 1 (2020): 57-66. https://doi.org/10.30596/dll.v5i1.3446.

David. "Hasil Wawancara Dengan David Selaku Kepala Bidang Pengkajian Dan Penanganan Sengketa Dan Konflik Pertanahan, Pada Tanggal 23 Februari 2021.” 2021.

Irwansyah. Penelitian Hukum: Pilihan Metode \& Praktik Penulisan Artikel. Edited by Ahsan Yunus. Yogyakarta: Mirra Buana Media, 2020.

Lamia, C. F. "Peralihan Hak Atas Tanah Warisan.” Lex Privatum 2, no. 3 (2014).

Maryuningrum, V. P., Triwahyudi, P., \& Darori, I. "Efektifitas Hibah Hak Atas Tanah Menurut Hukum Adat Dalam Pendaftaran Tanah Di Kabupaten Boyolali." (Doctoral Dissertation, Sebelas Maret University)., 2017, 96-104.

Santoso, Urip. Hukum Agraria Kajian Komprehensif. Jakarta: Kencana Prenada Media Group, 2012. 2010.

- "Penyelesaian Sengketa Dalam Pengadaan Tanah Untuk Kepentingan Umum." Perspektif 21, no. 3 (2016): 188-98.

Soekanto, Soerjono. Pengantar Penelitian Hukum. Jakarta: UI-Press, 2014.

Sutedi, Adrian. Sertifikat Hak Atas Tanah. Jakarta: Sinar Grafika, 2012.

Syukron. "Hasil Wawancara Dengan Syukron, Pada Tanggal 24 Februari 2021.” 2021.

Wiranegara, I. M. A., Wairocana, I. G. N., \& Wiryawan, I. W. "Tukar Menukar Hak Atas Tanah Antar Wilayah Oleh Pejabat Pembuat Akta Tanah." Acta Comitas: Jurnal Hukum Kenotariatan 2(2), no. Kenotariatan (2018): 213-18. 